Rikard Malmbeck, Daniel Magnusson, Stéphane Bourg, Michael Carrott, Andreas Geist*, Xavier Hérès, Manuel Miguirditchian, Giuseppe Modolo, Udo Müllich, Christian Sorel, Robin Taylor and Andreas Wilden

\title{
Homogenous recycling of transuranium elements from irradiated fast reactor fuel by the EURO- GANEX solvent extraction process
}

https://doi.org/10.1515/ract-2018-3089

Received December 5, 2018; accepted April 25, 2019; published online May 27, 2019

\begin{abstract}
The EURO-GANEX process was developed for co-separating transuranium elements from irradiated nuclear fuels. A hot flow-sheet trial was performed in a counter-current centrifugal contactor setup, using a genuine high active feed solution. Irradiated mixed (carbide, nitride) $\mathrm{U}_{80} \mathrm{Pu}_{20}$ fast reactor fuel containing $20 \% \mathrm{Pu}$ was thermally treated to oxidise it to the oxide form which was then dissolved in $\mathrm{HNO}_{3}$. From this solution uranium was separated to $>99.9 \%$ in a primary solvent extraction cycle using $1.0 \mathrm{~mol} / \mathrm{L}$ DEHiBA ( $N, N$-di(2-ethylhexyl)isobutyramide in TPH (hydrogenated tetrapropene) as the organic phase. The raffinate solution from this process, containing $10 \mathrm{~g} / \mathrm{L} \mathrm{Pu}$, was further processed in a second cycle of solvent extraction. In this EURO-GANEX flow-sheet, TRU and fission product lanthanides were firstly co-extracted into a solvent composed of $0.2 \mathrm{~mol} / \mathrm{L}$ TODGA $\left(N, N, N^{\prime}, N^{\prime}\right.$-tetra$n$-octyl diglycolamide) and $0.5 \mathrm{~mol} / \mathrm{L}$ DMDOHEMA ( $N, N^{\prime}$ dimethyl- $N, N^{\prime}$-dioctyl-2-(2-hexyloxy-ethyl) malonamide) dissolved in Exxsol D80, separating them from most other fission and corrosion products. Subsequently, the TRU were selectively stripped from the collected loaded solvent
\end{abstract}

\footnotetext{
*Corresponding author: Andreas Geist, Karlsruhe Institute of Technology (KIT), Institute for Nuclear Waste Disposal (INE), Karlsruhe, Germany, E-mail: andreas.geist@kit.edu

Rikard Malmbeck: European Commission, DG Joint Research Centre, Directorate G, Karlsruhe, Germany

Daniel Magnusson and Udo Müllich: Karlsruhe Institute of Technology (KIT), Institute for Nuclear Waste Disposal (INE), Karlsruhe, Germany

Stéphane Bourg, Xavier Hérès, Manuel Miguirditchian and Christian Sorel: French Alternative Energies and Atomic Energy Commission, Nuclear Energy Division, Research Department on Mining and Fuel Recycling Processes, CEA Marcoule, Bagnols sur Cèze, France Michael Carrott and Robin Taylor: National Nuclear Laboratory, Central Laboratory, Sellafield, Seascale, CA20 1PG, UK Giuseppe Modolo and Andreas Wilden: Forschungszentrum Jülich $\mathrm{GmbH}$, Institut für Energie- und Klimaforschung - Nukleare Entsorgung und Reaktorsicherheit, Jülich, Germany
}

using a solution containing $0.055 \mathrm{~mol} / \mathrm{L} \mathrm{SO}_{3}-\mathrm{Ph}$-BTP (2,6-bis(5,6-di(3-sulphophenyl)-1,2,4-triazin-3-yl)pyridine tetrasodium salt) and $1 \mathrm{~mol} / \mathrm{L}$ AHA (acetohydroxamic acid) in $0.5 \mathrm{~mol} / \mathrm{L} \mathrm{HNO}_{3}$; lanthanides were finally stripped using $0.01 \mathrm{~mol} / \mathrm{L} \mathrm{HNO}_{3}$. Approximately $99.9 \%$ of the TRU and less than $0.1 \%$ of the lanthanides were found in the product solution, which also contained the major fractions of $\mathrm{Zr}$ and Mo.

Keywords: Homogeneous recycling, TRU separation, solvent extraction, centrifugal contactor.

\section{Introduction}

Energy produced by nuclear power today means a demand of 65,000 metric tonnes natural uranium per year for nuclear fuels [1]. In turn, approximately 10,000 metric tonnes of spent nuclear fuels are discharged annually.

The fraction of uranium consumed during a once through irradiation in a reactor is in fact only approximately $0.6-0.7 \%$, slightly dependent on fuel enrichment and burn-up of the fuel. Although large deposits of uranium exist worldwide, the sustainability of electricity generation by nuclear fission can be massively enhanced by recycling the actinides, essentially plutonium, from used nuclear fuels.

By reprocessing the irradiated nuclear fuel once and recycling recovered plutonium together with reprocessed uranium, as done in France, the natural uranium consumption is reduced by $17 \%$ [2, 3]. A further significant reduction can be achieved by multi-recycling of fuels in reactors with a fast neutron spectrum and using the depleted uranium stockpiles. No natural uranium would be required in this case [2]. Furthermore, reprocessing reduces the amount of highly radioactive waste compared to the direct disposal of used nuclear fuel. The reduction is both with respect to volume (since the major component of used nuclear fuel, uranium, is removed during reprocessing) and with respect to long term heat generation 
(since plutonium is also removed). A further reduction in heat generation would be achieved by also separating the remaining minor actinides [4], neptunium, americium and curium, which will allow for a smaller final high-level waste (HLW) repository. In summary, recycling actinides saves two resources - natural uranium and space required for final repositories.

While the PUREX (plutonium uranium reduction extraction) process for separating uranium and plutonium from nuclear fuel by solvent extraction is used on a commercial scale, innovative processes for homogenous recycling of fast reactor fuels [5], i. e. grouped separation of both the major and the minor actinides, are currently under development. To date, only one concept has been demonstrated with irradiated nuclear fuel on the lab scale [6].

Major challenges are the high $\mathrm{Pu}$ concentration, the high specific radioactivity of fission products and ensuring selectivity between the actinides and the fission products. Single cycle concepts exist but at this point are rather exploratory. They are usually based on TBP (tri- $n$-butyl phosphate) extraction taking advantage of its capability to recover $\mathrm{U}(\mathrm{VI})$ and $\mathrm{Pu}(\mathrm{IV})$ at high loading. The co-recovery of minor actinides is incorporated by introducing a second extracting agent that shows high selectivity for the minor actinides over FPs, including chemically similar lanthanides. For example, the CHALMEX concept [7-9] uses a solventcontaining $\mathrm{CyMe}_{4}-\mathrm{BTBP}\left(6,6^{\prime}\right.$ 'bis(5,5,8,8-tetramethyl5,6,7,8-tetrahydro-benzo-1,2,4-triazin-3-yl)-2,2'-bipyridine, Figure 1) [10-11] plus TBP dissolved in a polar diluent such as cyclohexanone or FS-13 (phenyl trifluoromethyl sulfone) to directly extract only $\mathrm{U}$ and TRU from dissolved fuel solutions. The chemical system has promise but so far has not been tested in a counter-current flow-sheet trial.
A different approach is pursued in the US, exploiting the oxidation of Am(III) to Am(VI), making it extractable by e. g. TBP or phosphonate extracting agents [12-14]. This opens up the possibility of a single process to co-extract $U$, $\mathrm{Np}, \mathrm{Pu}$ and $\mathrm{Am}$.

The so called GANEX (grouped actinides extraction) process was initially developed at the CEA (Commissariat à l'énergie atomique et aux énergies alternatives) in France $[15,16]$. It consists of two cycles; the first cycle removes the large mass of uranium and the second cycle is to recover the trans-uranium elements (TRU: $\mathrm{Np}, \mathrm{Pu}, \mathrm{Am}, \mathrm{Cm}$ ).

The first cycle process is based on a selective $\mathrm{U}(\mathrm{VI})$ extraction from an aqueous phase of approximately $5 \mathrm{~mol} / \mathrm{L}$ $\mathrm{HNO}_{3}$ into DEHiBA ( $\mathrm{N}, \mathrm{N}$-di(2-ethylhexyl)isobutyramide, Figure 1) dissolved in TPH (hydrogenated tetrapropene), an industrial aliphatic diluent. Co-extracted Tc and Np are reduced and scrubbed by hydrazine in a scrubbing section at $1.5 \mathrm{~mol} / \mathrm{L} \mathrm{HNO}_{3}$ and thereby routed together with the TRU and the fission products (FP) to the high level raffinate (HAR). U(VI) is efficiently stripped from the organic phase into $0.01 \mathrm{~mol} / \mathrm{L} \mathrm{HNO}_{3}$. The first GANEX cycle has been demonstrated in the ATLANTE facility at the CEA using a high active feed solution from dissolved irradiated fuel [17].

The raffinate from the first cycle is the feed for the second GANEX cycle, where TRU (present as tri-, tetraand hexavalent actinides) are separated and selectively recovered: TRU, lanthanides, $\mathrm{Y}, \mathrm{Mo}, \mathrm{Tc}, \mathrm{Zr}$ and Fe are coextracted into a solvent containing DMDOHEMA ( $N, N^{\prime}$ dimethyl- $N, N^{\prime}$-dioctyl-2-(2-hexyloxy-ethyl) malonamide [18], Figure 1) and HDEHP (di(2-ethylhexyl)phosphoric acid, Figure 1) diluted in TPH. Several selective stripping stages are implemented. Firstly, Mo, Ru, Tc are stripped with $0.4 \mathrm{~mol} / \mathrm{L}$ citric acid at $\mathrm{pH}$ of 2.7, then TRU are stripped into a solution containing $0.5 \mathrm{~mol} / \mathrm{L} \mathrm{N}$-(2-hydroxyethyl)<smiles>CCCCC(CC)CN(CC(CC)CCC)C(=O)C(C)C</smiles><smiles>CCN(C)C(=O)C(CCOC)C(=O)N(C)C</smiles>

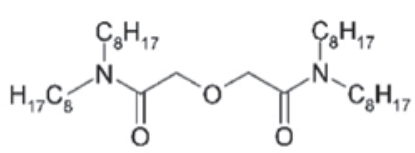
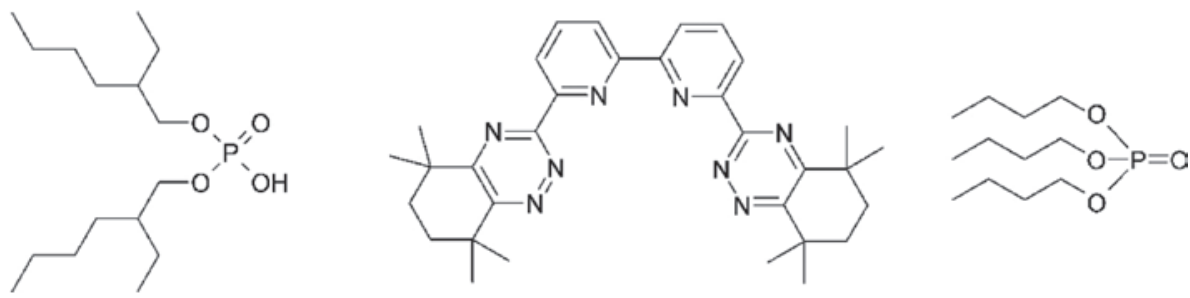

Figure 1: Extracting agents used in various GANEX flow-sheets: top, DEHiBA, DMDOHEMA, TODGA; bottom, HDEHP, CyMe 4 -BTBP, TBP. 
ethylenediaminetriacetic acid (HEDTA, Figure 2) and $0.5 \mathrm{~mol} / \mathrm{L}$ citric acid at $\mathrm{pH}=3$ with $0.1 \mathrm{~mol} / \mathrm{L}$ hydroxyurea, acting as a reducing agent for neptunium(VI). Finally, $\mathrm{Ln}, \mathrm{Zr}$ and Fe are recovered by $0.5 \mathrm{~mol} / \mathrm{L}$ oxalic acid and $0.2 \mathrm{~mol} / \mathrm{L}$ TEDGA (tetraethyl diglycolamide, Figure 2). The second GANEX cycle has also been demonstrated in the ATLANTE facility at the CEA using the high active raffinate from the first cycle test [19]. Although excellent results were obtained it was generally recognised that there is a need to simplify the rather complicated and $\mathrm{pH}$ sensitive stripping section.

In the framework of the EURATOM research project, ACSEPT [20], an alternative GANEX second cycle concept was developed, the EURO-GANEX process. The approach for selective TRU stripping is based on the selectivity of a novel water soluble BTP molecule for complexation with trivalent actinides compared to the trivalent lanthanides. This enables stripping at higher acidities and thereby removes the need to control $\mathrm{pH}$.

The EURO-GANEX solvent is $0.2 \mathrm{~mol} / \mathrm{L}$ TODGA $\left(N, N, N^{\prime}\right.$, $N^{\prime}$-tetra- $n$-octyl diglycolamide [21], Figure 1) $+0.5 \mathrm{~mol} / \mathrm{L}$ DMDOHEMA in Exxsol D80 (a kerosene diluent). This solvent co-extracts $\mathrm{Np}$ (VI), Pu(IV), Am(III), Cm(III) and Ln(III) from the GANEX first cycle raffinate [22-25] and is capable of high $\mathrm{Pu}(\mathrm{IV})$ loading capacity, up to $40 \mathrm{~g} / \mathrm{L}$ depending on acidity, in contrast to many other solvents tested [26]. DMDOHEMA is expected to act primarily as a phase modifier but its role is not perfectly clear. Indeed, malonamides extract An(IV) much more efficiently than An(III) [27]. Hence, DMDOHEMA may also contribute to $\mathrm{Pu}$ (IV) extraction. $\mathrm{Zr}$ (IV) and $\mathrm{Pd}(\mathrm{II})$ are masked using CDTA (trans-1,2-cyclohexanediaminetetraacetic acid, Figure 2) [28]; co-extracted $\mathrm{Sr}(\mathrm{II})$ and $\mathrm{Fe}(\mathrm{III})$ are scrubbed using $0.5 \mathrm{~mol} / \mathrm{L} \mathrm{HNO}_{3}$. TRU are stripped from the loaded solvent using a strip solution containing $\mathrm{SO}_{3}$ Ph-BTP (2,6-bis(5,6-di(3-sulphophenyl)-1,2,4-triazin-3-yl) pyridine tetrasodium salt, Figure 2) [29] and AHA (acetohydroxamic acid, Figure 2) [30] while Ln(III) are kept in the solvent by a sufficiently high concentration of $\mathrm{HNO}_{3}$ in the strip phase. A first "Pu-active" test (i. e. using a surrogate feed solution containing a representative $\mathrm{Pu}(\mathrm{IV})$ concentration and spiked with $\mathrm{Np}$ and $\mathrm{Am}$ ) proved the principle. Excellent results regarding hydrodynamics and $\mathrm{Pu}$ and Am recovery were obtained. However, approximately $30 \%$ of $\mathrm{Np}$ was routed to the raffinate and approximately $7 \%$ of Eu (representing the Ln) was routed to the TRU product [31]. A slightly modified flow-sheet was later developed at NNL (National Nuclear Laboratory, UK), producing separate $\mathrm{Np}+\mathrm{Pu}$ and $\mathrm{Am}+\mathrm{Cm}$ product solutions for potential applications in the heterogeneous recycling of actinides [32].

Based on the experience gained with the $\mathrm{Pu}$-active test [31], the EURO-GANEX process was finally "hot tested" using genuine dissolved spent fuel as the feed solution. This solution was obtained by performing a GANEX first cycle run on a feed solution prepared by dissolving irradiated fast reactor fuel. This paper is a full report on the development and execution of the hot test. It reports on the adapted first and second cycle flow-sheets, feed solution preparation and results from the hot first and second cycle process tests. For further experimental details see Annex - Experimental.

\section{Fuel dissolution}

Fast reactor $(\mathrm{FR})$ fuel $\left(\mathrm{U}_{80} \mathrm{Pu}_{20}\right)$ with stainless steel cladding taken from a selection of mixed FR fuels of $(\mathrm{U}, \mathrm{Pu}) \mathrm{N}$,<smiles>O=C(O)CN(CCO)CCN(CC(=O)O)CC(=O)O</smiles><smiles>NC(=O)NO</smiles><smiles>CN(C)C(=O)COCC(=O)N(C)C</smiles><smiles>O=C(O)CN(CC(=O)O)C1CCCCC1N(CC(=O)O)CC(=O)O</smiles><smiles>NS(=O)(=O)c1cccc(-c2nnc(-c3cccc(-c4nnc(-c5cccc(S(=O)(=O)O)c5)c(-c5cccc(S(N)(=O)=O)c5)n4)n3)nc2-c2cccc(S(N)(=O)=O)c2)c1</smiles><smiles>CC(=O)NO</smiles>

Figure 2: Water soluble complexing and reducing agents used in various GANEX flow-sheets: top, HEDTA, hydroxyurea, TEDGA; bottom, CDTA, $\mathrm{SO}_{3}$-Ph-BTP, AHA. 
(U,Pu)C or $(\mathrm{U}, \mathrm{Pu}) \mathrm{N}, \mathrm{C}$, irradiated between 1971 and 1976 in the Dounreay (UK) Fast Reactor (DFR) was used. These were some legacy fuels still held at the Joint Research Centre (JRC), Karlsruhe, Germany. The fuel pieces could not be assigned to a certain irradiation experiment. Therefore, the irradiation history and burn-up is unknown. The selected fuel pieces were approximately $8 \mathrm{~mm}$ long.

In total, $116.8 \mathrm{~g}$ (with cladding) of fast reactor fuel pieces was thermally treated to oxidise the carbides and nitrides to oxides, yielding predominantly $\mathrm{U}_{3} \mathrm{O}_{8}$. For the oxidation process the fuel pieces were added to an alumina crucible, placed in a furnace in a hot cell and kept for 3 days under a slow air flow at a temperature of $600^{\circ} \mathrm{C}$ [33]. The off-gas was treated by three alkaline gas traps attached to the set-up to capture iodine. Following this treatment, the fuel was completely powderised. The cladding pieces were visually inspected and appeared to be clean.

The powderised oxide material was subsequently dissolved in $600 \mathrm{~mL}$ of $6 \mathrm{~mol} / \mathrm{L} \mathrm{HNO}_{3}$ by refluxing for $8 \mathrm{~h}$. The solution was filtered twice $(20 \mu \mathrm{m}$ and $0.45 \mu \mathrm{m})$, producing

Table 1: ICP-MS analysis of collected fractions from the GANEX first cycle.

\begin{tabular}{lrrlll}
\hline & Feed & Raffinate & $\begin{array}{l}\text { Loaded } \\
\text { solvent }\end{array}$ & U product & $\begin{array}{l}\text { Stripped } \\
\text { solvent }\end{array}$ \\
\hline $\mathrm{U}$ & 103,300 & 61 & 32,300 & $\mathrm{a}$ & 20 \\
$\mathrm{~Np}$ & 17 & 13 & 0.2 & 0.4 & $<\mathrm{LOD}$ \\
$\mathrm{Pu}$ & 22,700 & 18,100 & 8 & 34 & $<$ LOD \\
$\mathrm{Am}$ & 330 & 246 & $<\mathrm{LOD}$ & 0.3 & $<$ LOD \\
Total Ln & 860 & 726 & $<$ LOD & 0.7 & $<$ LOD \\
Tc & 41 & 18.3 & 2.8 & 3.5 & 1.6 \\
\hline
\end{tabular}

aU concentration in product solution was obviously erroneous. Concentrations in $\mathrm{mg} / \mathrm{L}(<\mathrm{LOD}=$ below limit of detection).
$741.7 \mathrm{~g}$ solution and (after drying) $8.6 \mathrm{~g}$ precipitates and 17.9 g cladding material.

This solution was characterised by ICP-MS measurements for metals concentration (see Table 1) and titration for the acidity. The solution was then adjusted to a $\mathrm{HNO}_{3}$ concentration of $5 \mathrm{~mol} / \mathrm{L}$ by adding concentrated $\mathrm{HNO}_{3}$, producing approximately $620 \mathrm{~mL}$ of feed solution for the GANEX first cycle.

\section{GANEX first cycle: $U$ separation}

\subsection{Flow-sheet}

The previous hot GANEX first cycle test [17] was carried out in mixer settlers at CEA's ATALANTE facility. The uranium and plutonium feed concentrations were $176 \mathrm{~g} / \mathrm{L}$ and 2.5 $\mathrm{g} / \mathrm{L}$, respectively. Based on the experiences gained from this test, a new flow-sheet was designed using the CEA's PAREX code [34], see Figure 3.

A physicochemical model was developed and implemented in PAREX, based on experimental distribution ratios of $\mathrm{HNO}_{3}, \mathrm{U}$ [35], $\mathrm{Pu}$ and Tc [36], disregarding organic activity coefficients. The $\mathrm{UO}_{2}\left(\mathrm{NO}_{3}\right)_{2}^{-}$ $\mathrm{HNO}_{3}-\mathrm{H}_{2} \mathrm{O} / \mathrm{DEHiBA}-\mathrm{TPH}$ system could be modelled taking into account three acid complexes and only one $\mathrm{U}$ complex, (DEHiBA) $\left(\mathrm{UO}_{2}\left(\mathrm{NO}_{3}\right)_{2}\right)$, in the organic phase. The extraction of $\mathrm{Pu}(\mathrm{IV})$ and $\mathrm{Np}(\mathrm{VI})$ was also represented by organic complexes involving two DEHiBA molecules, as in the case for $\mathrm{U}(\mathrm{VI})$. The extraction of $\mathrm{Np}(\mathrm{V})$ was modelled by considering the formation of the organic complex (DEHiBA) $\left(\mathrm{NpO}_{2}\left(\mathrm{NO}_{3}\right)\right)$. The behaviour of Tc(VII), particularly in the presence of U(VI), governs the design of the scrubbing section. The extraction of pertechnetic acid

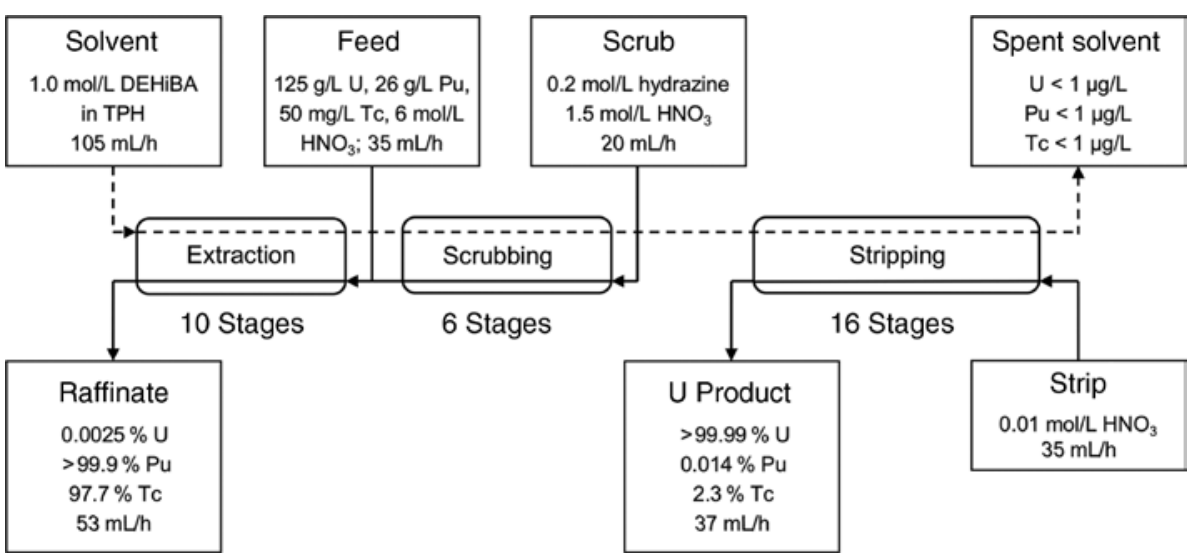

Figure 3: Adapted GANEX first cycle flow-sheet with calculated recoveries. 
from a nitric acid solution can be accurately calculated taking into account the complexes (DEHiBA) $\left(\mathrm{HTcO}_{4}\right)$ and (DEHiBA $)_{2}\left(\mathrm{HTCO}_{4}\right)$. However, in the presence of uranyl nitrate, a mixed complex (DEHiBA) $)_{2}\left(\mathrm{UO}_{2}\left(\mathrm{NO}_{3}\right)\left(\mathrm{TcO}_{4}\right)\right)$ has to be considered as well.

Recently, the model was improved by the acquisition of new binary data for $\mathrm{HTcO}_{4}$ [37], considering three complexes for $\mathrm{HTcO}_{4}$ extraction by DEHiBA: (DEHiBA $)_{4}\left(\mathrm{HTcO}_{4}\right)$, $(\mathrm{DEHiBA})_{3}\left(\mathrm{HTCO}_{4}\right)\left(\mathrm{HNO}_{3}\right)$ and $(\mathrm{DEHiBA})_{2}\left(\mathrm{HTCO}_{4}\right)\left(\mathrm{HNO}_{3}\right)$. Furthermore, an additional complex (DEHiBA) ${ }_{3}\left(\mathrm{UO}_{2}\left(\mathrm{NO}_{3}\right)\right.$ $\left(\mathrm{TcO}_{4}\right)\left(\mathrm{HNO}_{3}\right)$ was taken into account to improve $\mathrm{U}$ and $\mathrm{TcO}_{4}^{-}$extraction at elevated $\mathrm{HNO}_{3}$ concentrations [38].

In comparison to the previous experiment, which reprocessed light water reactor (LWR) uranium oxide fuel in miniature mixer-settlers [17], modelling this flow-sheet had to account for the lower $U$ feed concentration and the shorter hold up times of the 16-stage centrifugal contactor cascade used at the JRC. The higher concentration of $\mathrm{Pu}$ in this test has no impact on uranium extraction performance since $\mathrm{Pu}$ is only very slightly extracted. The total aqueous and organic flows were adapted in order to maintain sufficient residence time to ensure efficient uranium extraction and scrubbing. Furthermore, the organic/ aqueous flow-rate ratio in the extraction section was decreased from 2.2 to 1.9 to account for the lower concentration of $\mathrm{U}$ in the feed (125 g/L vs. $176 \mathrm{~g} / \mathrm{L}$ [17]). The flow rate ratio in the scrubbing section was kept unchanged. Since 16 stages (instead of 8 in the previous test) were proposed to strip uranium, it was possible to decrease the aqueous flow rate of the stripping section, yielding a more concentrated uranium product solution $(125 \mathrm{~g} / \mathrm{L}$ instead of $90 \mathrm{~g} / \mathrm{L})$.

The proposed first cycle flow-sheet is shown in Figure 3, together with calculated relative concentrations of actinides and technetium in the product and raffinate solutions.

\subsection{Hot test}

Due to the limited number of centrifugal contactors (16) available in the JRC hot cell facility, the GANEX first cycle test had to be run in two steps. The first step was extraction and scrubbing, yielding the raffinate containing the TRU that was to be used as the feed solution for the EUROGANEX (second cycle) run. The loaded organic phase, containing $\mathrm{U}$, was collected and back-extracted in the second step.

\subsubsection{Part 1, preparation of the raffinate containing TRU}

The flow-sheet which was run to prepare the TRU-containing raffinate is shown in Figure 4. Analysis of the feed solution revealed that it was diluted by a factor of 1.2 compared to what was assumed when calculating the flow-sheet. To compensate for the lower extractability of $\mathrm{U}$ due to the lower $\mathrm{HNO}_{3}$ concentration ( $5 \mathrm{~mol} / \mathrm{L}$ instead of $6 \mathrm{~mol} / \mathrm{L}$ ), flow-rates were adapted using the PAREX code. The organic to aqueous flow-rate ratio was raised from 1.9 to 2.2. The resulting lower $U$ concentration in the organic phase is expected to reduce Tc co-extraction due to mixed U-Tc complexes, allowing an increase of the organic to aqueous phase flow-rate in the scrubbing section from 5.25 to 6 .

The total running time to process the complete feed solution required that the experiment was run overnight. Due to experimental restrictions in the hot cell all flowrates were down-scaled by a factor of 0.75 . The final flowsheet is shown in Figure 4.

The test was started up with a surrogate feed solution

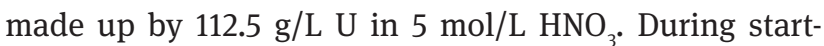
up, the organic product contained aqueous entrainment which was caused by a maloperation of contactor 16 . This

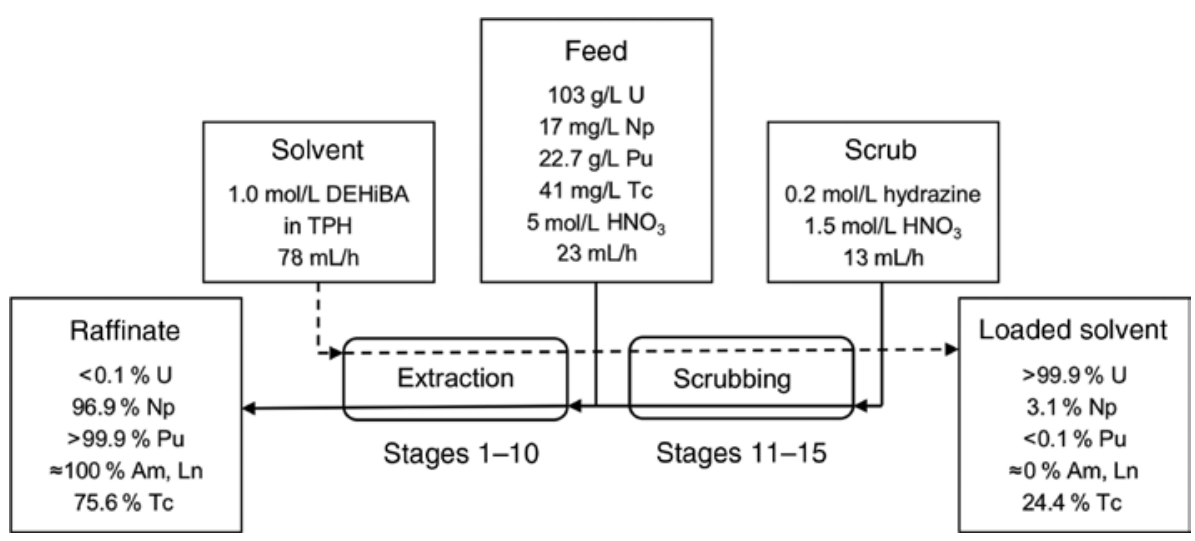

Figure 4: GANEX first cycle run, part 1, extraction and scrubbing: flow-sheet with measured flow rates and recoveries. 
problem was solved by feeding the scrub solution to contactor 15 instead of contactor 16. Otherwise, the test ran for $16 \mathrm{~h}$ (with the genuine irradiated fuel feed) without further problems, yielding approximately $600 \mathrm{~mL}$ of raffinate solution, enough to be used as the feed for the second cycle test.

Excellent results were obtained (cf. Figures 4 and 5). $\mathrm{U}$ was almost completely routed to the loaded solvent, which contained approximately $3 \%$ of the Np inventory and only approximately $0.1 \%$ of the $\mathrm{Pu}$ inventory. Am and Ln were "quantitatively" routed to the raffinate, i.e. their concentrations in the loaded organic phase were below detection limits. Approximately one quarter of the Tc inventory was extracted, which is more than predicted by the initial calculations. This result is mainly explained by shorter residence times and a lower number of stages in the scrubbing section compared to the previous test performed in mixer-settlers. Tc(VII) reduction kinetics by hydrazine being relatively slow, the residence time might not have been sufficient to achieve a more complete stripping of Tc from the solvent. Nevertheless, a raffinate solution suitable as second cycle feed solution was produced, containing most of TRU and Ln, some Tc and almost no U.

\subsubsection{Part 2, U back extraction}

The collected loaded solvent was stored overnight and back-extracted on the following day. Sixteen stages were used to back extract $\mathrm{U}$, the organic flow rate was $78 \mathrm{~mL} / \mathrm{h}$ and the strip phase used was $0.01 \mathrm{~mol} / \mathrm{L} \mathrm{HNO}_{3}$ at $73 \mathrm{~mL} / \mathrm{h}$. After back extraction, the organic effluent contained $<0.04 \%$ of the $\mathrm{U}$ initially present in the loaded solvent, whereas $\mathrm{Pu}, \mathrm{Am}$ and $\mathrm{Ln}$ were below the detection limit (LOD). Analysis of the $\mathrm{U}$ product revealed a fraction of

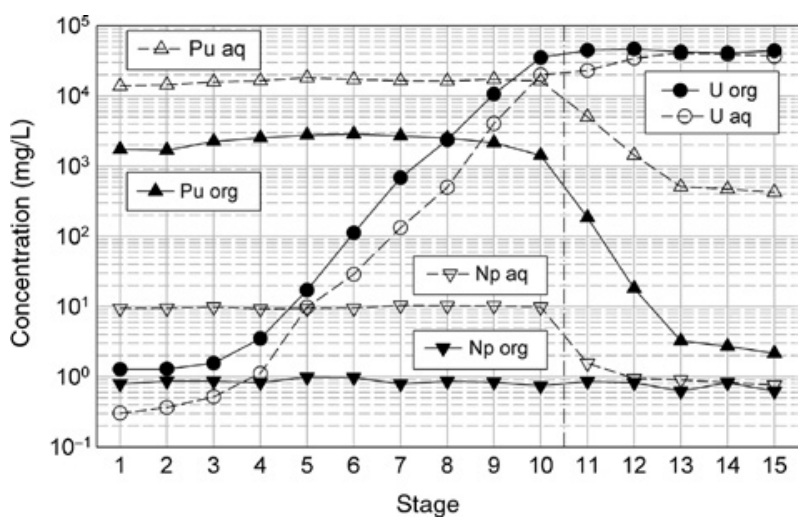

Figure 5: GANEX first cycle run, part 1, extraction (stages 1-10) and scrubbing (stages 11-15): U, Np and Pu concentration profiles. Vertical line, feed point. approximately $0.1 \%$ of the TRUs and $21 \%$ of Tc. Approximately $10 \%$ of the extracted Tc remained in the organic effluent after back-extraction. As demonstrated in the previous hot test [17], this can be minimised by using a more efficient scrubbing section (with eight instead of five stages). Alternatively, back extraction kinetics is accelerated by increasing the temperature of the scrubbing section to $35-40{ }^{\circ} \mathrm{C}$.

\subsubsection{GANEX first cycle, summary}

Table 1 summarises the concentrations of the major elements obtained in the first cycle GANEX test. Essentially all uranium was selectively removed and all other actinides were routed to the raffinate. The main goal of this experiment was, therefore, demonstrated, i.e. removal of the major fraction of uranium before the GANEX second cycle. As expected, the high concentration of $\mathrm{Pu}, 22.7 \mathrm{~g} / \mathrm{L}$, did not influence the performance of the process. Approximately $600 \mathrm{~mL}$ of feed solution for the GANEX second cycle was produced, sufficient for a demonstration test, which was the main purpose of the GANEX first cycle flowsheet trial. An additional benefit, however, was the first successful demonstration of the GANEX first cycle in short residence time centrifugal contactors with a fast reactor fuel composition (high $\mathrm{Pu}$ content). Improvements in neptunium and technetium are needed but further optimisation of the scrubbing section is expected to address these minor issues.

\section{EURO-GANEX (GANEX second cycle): TRU separation}

The second GANEX cycle recovers TRU from the first cycle raffinate. The EURO-GANEX process [22] does this by coextracting $\mathrm{Np}(\mathrm{VI}), \mathrm{Pu}(\mathrm{IV}), \mathrm{Am}(\mathrm{III}), \mathrm{Cm}(\mathrm{III})$ and $\mathrm{Ln}$ (III) into a solvent containing TODGA as the main extracting agent with DMDOHEMA added to allow for sufficiently high $\mathrm{Pu}(\mathrm{IV})$ loading $[23,26]$. TRU are stripped from the solvent using a combination of two complexing agents, $\mathrm{SO}_{3}-\mathrm{Ph}$ BTP [29] and AHA [30]. Finally, Ln(III) are stripped into $0.01 \mathrm{~mol} / \mathrm{L} \mathrm{HNO}_{3}$.

\subsection{Flow-sheet}

The flow-sheet used for the second cycle hot test is based on the flow-sheet tested in the "Pu-active" centrifugal contactor trials with a surrogate feed [31]. Following further modelling using the PAREX code, several modifications 
were introduced to improve the control of key species (specifically $\mathrm{Np}$, lanthanides) across the flow-sheet whilst adapting to the 16 stage set-up available for the hot test.

To help promote $\mathrm{Np}(\mathrm{V})$ oxidation to $\mathrm{Np}(\mathrm{VI})$ which is better extracted [23], the acidity of the feed solution was increased to $5.9 \mathrm{~mol} / \mathrm{L}_{\mathrm{HNO}_{3}}$. Rather than using eight stages for extraction and eight stages for scrubbing as was done in the Pu-active test, 12 stages were allocated for extraction and four stages for scrubbing. This change also aimed at optimising retention of $\mathrm{Np}(\mathrm{VI})$ in the organic phase resulting in improved $\mathrm{Np}$ extraction. The lower number of stages in the scrubbing section also reduced recycling and accumulation of Sr(II) between the extraction and scrubbing sections.

Finally, the TRU stripping section was modified to both simplify the set up in the hot cell and improve lanthanide decontamination. Calculations showed it would be possible to feed one stripping solution (containing $0.055 \mathrm{~mol} / \mathrm{L} \mathrm{SO}_{3}-\mathrm{Ph}$-BTP and $1 \mathrm{~mol} / \mathrm{L} \mathrm{AHA}$ ) instead of the split stripping with two separate feeds into different stages (containing different concentrations of $\mathrm{SO}_{3}$-Ph-BTP) as was used in the "Pu-active" test [31] whilst maintaining the efficient stripping of the actinides.

As 16 stages are not enough to cover the complete flow-sheet, the demonstration test was again divided into two parts to be run on consecutive days: 16 stages for extraction and scrubbing and 16 stages for back extraction. The respective flow-sheets are shown in Figure 6 (extract-scrub section) and Figure 12 (TRU back extraction/Ln re-extraction and Ln back extraction).

\subsection{Hot test}

The raffinate collected from the first cycle was conditioned before feeding to the extraction process. Conditioning involved dilution with $\mathrm{HNO}_{3}$ by a factor of 1.8 to yield the target $\mathrm{Pu}$ feed concentration of $10 \mathrm{~g} / \mathrm{L}$ (as used in the surrogate test [31]) and to increase the $\mathrm{HNO}_{3}$ concentration to $5.9 \mathrm{~mol} / \mathrm{L}$. $0.055 \mathrm{~mol} / \mathrm{L}$ CDTA was added to suppress $\mathrm{Zr}$ and Pd extraction. The Np concentration was actually increased by adding Np-237 in order to ease the analysis.

\subsubsection{Part 1, preparation of the loaded solvent}

The flow-sheet for the first run, comprising extraction and scrubbing sections, is shown in Figure 6. The test was run for $6 \mathrm{~h}$ to attain steady state and a further $10 \mathrm{~h}$ to collect $300 \mathrm{~mL}$ of loaded solvent, sufficient for the subsequent TRU stripping run.

The major results were as follows (see also Figure 6 and Table 2): TRU and Ln were almost completely extracted to the organic phase; less than $0.1 \%$ of $\mathrm{Np}$ and approximately $0.01 \%$ each of $\mathrm{Pu}, \mathrm{Am}$ and $\mathrm{Ln}$ were lost to the raffinate. The respective concentration profiles are shown in Figures 7 and 8. Other than TRU and Ln, the loaded organic phase also contained some $\mathrm{Zr}$, Mo, $\mathrm{Tc}$ and $\mathrm{Ru}$ (as predicted from batch experiments [22]); other non-Ln fission products concentrations were in the sub-ppm range. The respective profiles are shown in Figures 9-11.

$\mathrm{Pu}, \mathrm{Am}$ and $\mathrm{Ln}$ were very well extracted, as evident from the steep concentration profiles for stages 10-12 (see Figures 7 and 8). The flat profiles in stages 1-9 are most probably due to concentrations being below the limits of detection and/or contamination during sampling and analysis in the hot cell. The concentration profiles in the scrubbing section (stages 13-16) show that Pu, Am and Ln remained in the organic phase, as expected.

The Np concentration profile in the extraction section was less steep than the $\mathrm{Pu}$ and Am profiles. Since $\mathrm{Np}(\mathrm{VI})$ is readily extractable into the organic phase it is an indication of the presence of lesser extractable $\mathrm{Np}(\mathrm{V})$ even though the aqueous $\mathrm{HNO}_{3}$ concentration in the extraction section was approximately $3.2 \mathrm{~mol} / \mathrm{L}$. Np also

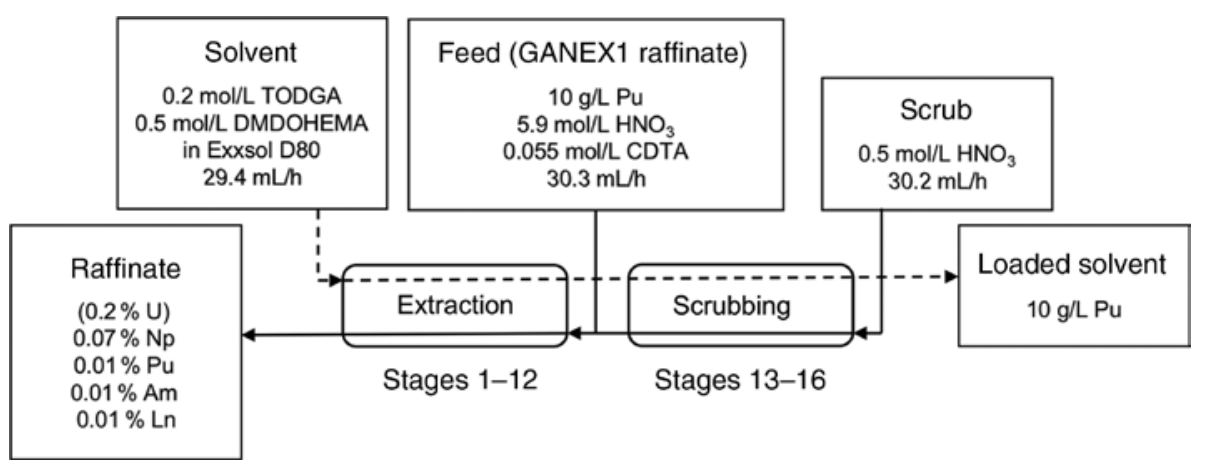

Figure 6: EURO-GANEX run, part 1 (preparation of loaded solvent), extraction and scrubbing: flow-sheet with measured flow rates and recoveries. 
Table 2: EURO-GANEX run, part 1, ICP-MS analysis of feed, raffinate and loaded solvent.

\begin{tabular}{|c|c|c|c|c|}
\hline & Feed & Raffinate & Loaded solvent & $\%$ mass balance \\
\hline $\mathrm{Fe}^{\mathrm{a}}$ & - & $30^{\mathrm{b}}$ & $<\mathrm{LOD}^{\mathrm{b}}$ & - \\
\hline $\mathrm{Sr}^{\mathrm{a}}$ & 13 & 3.9 & $<\mathrm{LOD}$ & 59 \\
\hline $\mathrm{Zr}$ & 135 & 54 & 23 & 97 \\
\hline Mo & 93 & 6.4 & 80 & 98 \\
\hline Tc & $2.5^{\mathrm{b}}(12)$ & 0.02 & 2.4 & $95^{\mathrm{b}}(19)$ \\
\hline $\mathrm{Ru}$ & $6^{\mathrm{b}}(9.3)$ & 2.1 & 2.2 & $105^{\mathrm{b}}(68)$ \\
\hline $\mathrm{Rh}$ & 5.2 & 2.5 & 0.03 & 97 \\
\hline $\mathrm{Pd}$ & 12 & $6^{b}(9.9)$ & $0.2^{\mathrm{b}}(1.0)$ & $101^{\mathrm{b}}(173)$ \\
\hline $\mathrm{Ag}$ & 3.5 & $2^{b}(0.4)$ & 0.06 & $115^{b}(24)$ \\
\hline $\mathrm{Cd}$ & 2.6 & 1.1 & 0.5 & 106 \\
\hline Sn & 1.1 & 0.4 & 0.6 & 127 \\
\hline $\mathrm{Sb}$ & 0.24 & 0.07 & 0.2 & 130 \\
\hline $\mathrm{Te}$ & 5.4 & 2.7 & 0.03 & 100 \\
\hline $\mathrm{Cs}$ & 139 & 68 & 0.02 & 98 \\
\hline $\mathrm{Ba}$ & 51 & 20 & 0.05 & 76 \\
\hline $\mathrm{La}$ & 49 & 0.001 & 49 & 98 \\
\hline $\mathrm{Ce}$ & 79 & $<L O D$ & 83 & 102 \\
\hline $\operatorname{Pr}$ & 44 & $<L O D$ & 45 & 100 \\
\hline $\mathrm{Nd}$ & 156 & 0.002 & 170 & 106 \\
\hline $\mathrm{Sm}$ & 35 & 0.02 & 37 & 102 \\
\hline $\mathrm{Eu}$ & 6.3 & 0.007 & 6.1 & 94 \\
\hline $\mathrm{Gd}$ & 5.7 & 0.01 & 7.2 & 124 \\
\hline $\mathrm{Tb}$ & 0.8 & $<\mathrm{LOD}$ & 0.8 & 99 \\
\hline Dy & 1.2 & $<L O D$ & 1.3 & 107 \\
\hline $\mathrm{U}$ & 68 & 0.1 & 87 & 125 \\
\hline $\mathrm{Np}$ & 97 & 0.03 & 88 & 88 \\
\hline $\mathrm{Pu}$ & 10,200 & 0.04 & 10,200 & 98 \\
\hline $\mathrm{Am}$ & 117 & 0.001 & 125 & 103 \\
\hline $\mathrm{Cm}$ & 0.01 & $<L O D$ & 0.02 & 230 \\
\hline
\end{tabular}

${ }^{\mathrm{a}} \mathrm{Fe}$ and $\mathrm{Sr}$ did not attain steady state.

balues taken from analysis of contactor wells (feed, stage 12; raffinate, stage 1; loaded solvent, stage 16$)$. Values from feed, raffinate and loaded solvent vessels given in parentheses. Concentrations in $\mathrm{mg} / \mathrm{L}$.

showed some accumulation in the scrubbing section where $0.5 \mathrm{~mol} / \mathrm{L} \mathrm{HNO}_{3}$ is introduced as the scrub acid feed. It is well known that Np has a complex redox chemistry in $\mathrm{HNO}_{3}$ [39] with the equilibrium between $\mathrm{Np}(\mathrm{V})$ and $\mathrm{Np}$ (VI) depending on nitric and nitrous acid concentrations (nitrous acid is a radiolysis product of $\mathrm{HNO}_{3}$ ) [40]. $\mathrm{Np}(\mathrm{V})$ also disproportionates to $\mathrm{Np}(\mathrm{IV})$ and $\mathrm{Np}(\mathrm{VI})$ at high $\mathrm{HNO}_{3}$ concentrations [39] and disproportionation is rapid in the organic phase [23]. The Np profile, therefore, reflects the changing $\mathrm{Np}$ oxidation state through the contactor bank as well as the differing extractabilities of the oxidation states (IV), (V) and (VI). Models of $\mathrm{Np}$ extraction have been developed for the analogous PUREX extract-scrub flowsheet that can be adapted to explain the behaviour of $\mathrm{Np}$ in the EURO-GANEX process [41-42]. However, in this test it was proven that

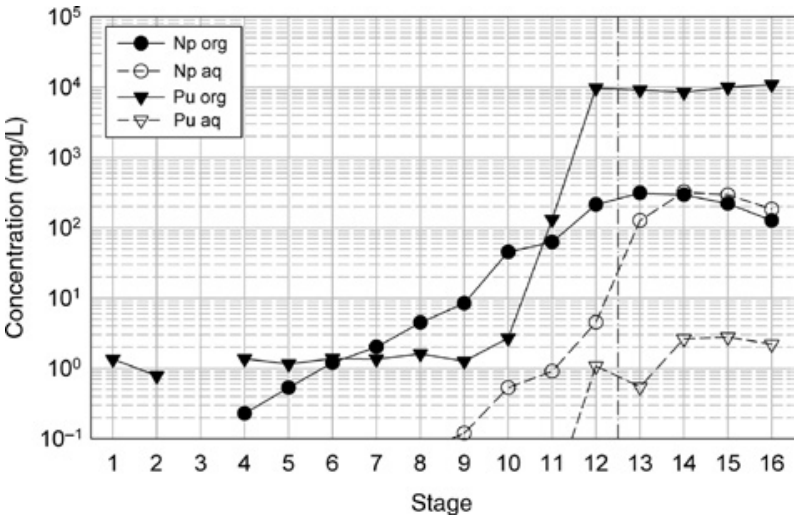

Figure 7: EURO-GANEX run, part 1 (preparation of loaded solvent), extraction (stages 1-12) and scrubbing (stages 13-16): $\mathrm{Np}$ and $\mathrm{Pu}$ concentration profiles.

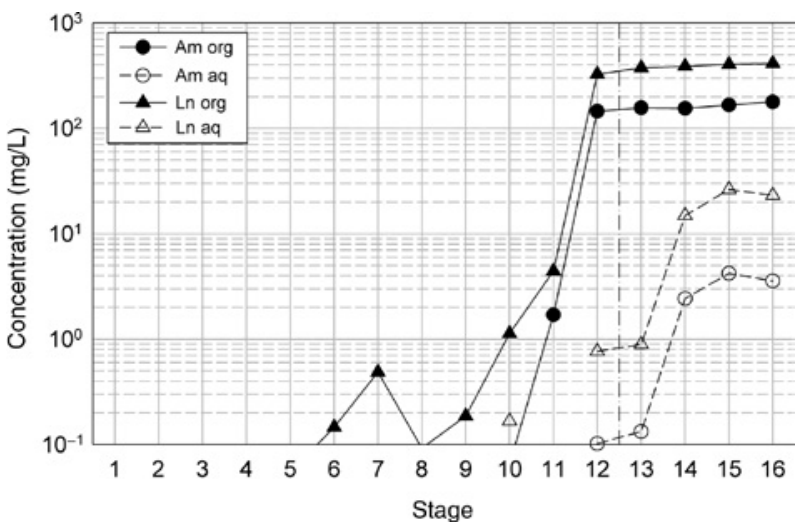

Figure 8: EURO-GANEX run, part 1 (preparation of loaded solvent), extraction (stages 1-12) and scrubbing (stages 13-16): Am and total Ln (=La-Dy) concentration profiles.

$\mathrm{Np}$ reached a steady state value, where the feed input of $\mathrm{Np}$ to the scrub section balanced the organic output from stage 16 , and that $>99 \% \mathrm{~Np}$ was routed with the organic phase in the extract-scrub section which is substantial improvement over the 'cold' test with a surrogate feed where $\approx 30 \%$ was lost to the HA raffinate [31]. This can be attributed to the radiolytic generation of $\mathrm{HNO}_{2}$ in the hot test that then catalysed the $\mathrm{HNO}_{3}$ oxidation of $\mathrm{Np}(\mathrm{V})$ to $\mathrm{Np}(\mathrm{VI})$ and also the higher acidity of the feed that reduced the stability of $\mathrm{Np}(\mathrm{V})$.

Fe and Sr were extracted in the extraction section and both were very well back-extracted in the scrubbing section, leading to significant accumulation in the extraction section (Figure 9). This was to be expected from the respective distribution ratios, being $>1$ at the nitric acid concentration present in the extraction section and $<1$ in the scrubbing section [22]. The accumulation leads to increased concentrations and flatter extraction profiles across the extraction section. Fe and Sr were thereby 


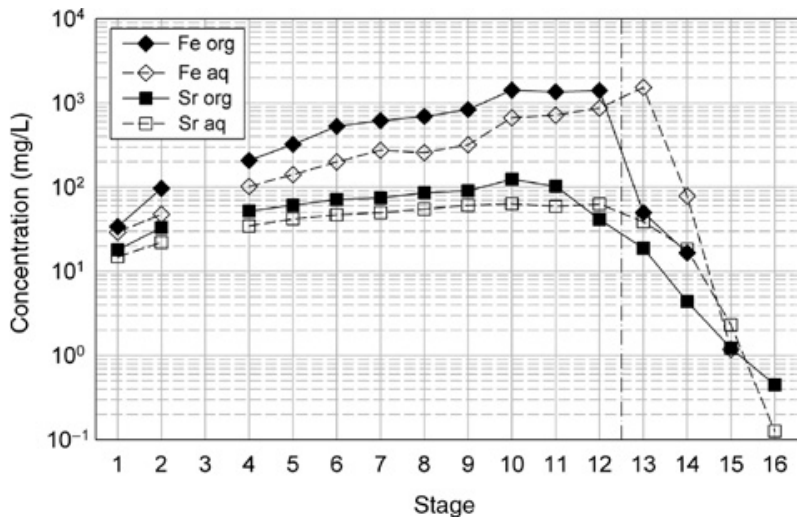

Figure 9: EURO-GANEX run, part 1 (preparation of loaded solvent), extraction (stages 1-12) and scrubbing (stages 13-16): Fe and Sr concentration profiles.

routed into the raffinate with only minor losses to the $\mathrm{Pu}$ loaded organic phase. The profiles and mass balances indicate that steady state was not achieved for Fe and Sr.

$\mathrm{Zr}, \mathrm{Ru}, \mathrm{Pd}$ and $\mathrm{Ag}$ showed little extraction; the small fractions extracted were not scrubbed but stayed in the organic phase (Figure 10). The behaviour of $\mathrm{Zr}$, Pd and Ag is explained by the effect of CDTA which was added to the feed solution and suppresses the extraction of these solutes [28]. CDTA was not added to the scrub solution: owing to the formation of stable organic species with very slow kinetics, back-extraction of Zr, Pd with CDTA is inefficient [28]. Hence, the fractions of $\mathrm{Zr}$, Pd and $\mathrm{Ag}$ which were extracted in the extraction section were not backextracted in the scrubbing section. Ruthenium is known to have a very complex behaviour with a range of species present in nitric acid and is difficult to decontaminate in the PUREX process [43]. Similar behaviour was observed in other processes using TODGA [44-45] or DMDOHEMA

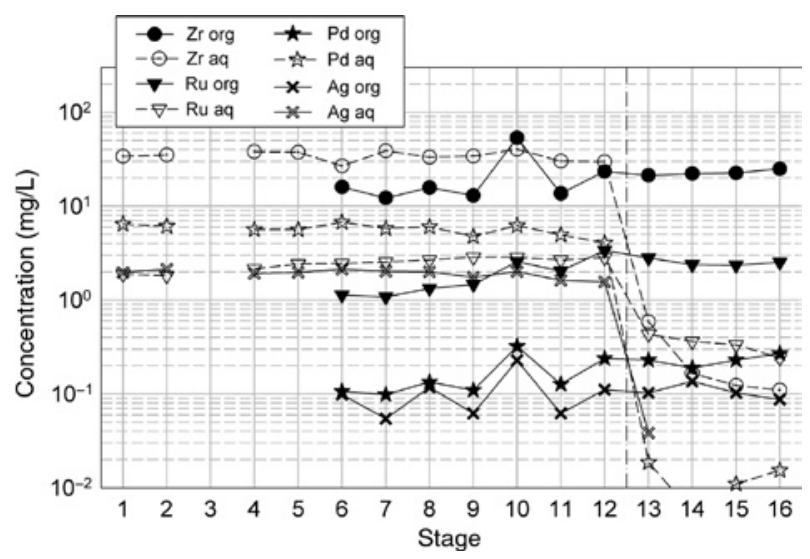

Figure 10: EURO-GANEX run, part 1 (preparation of loaded solvent), extraction (stages 1-12) and scrubbing (stages 13-16): Zr, Ru, Pd and $\mathrm{Ag}$ concentration profiles.

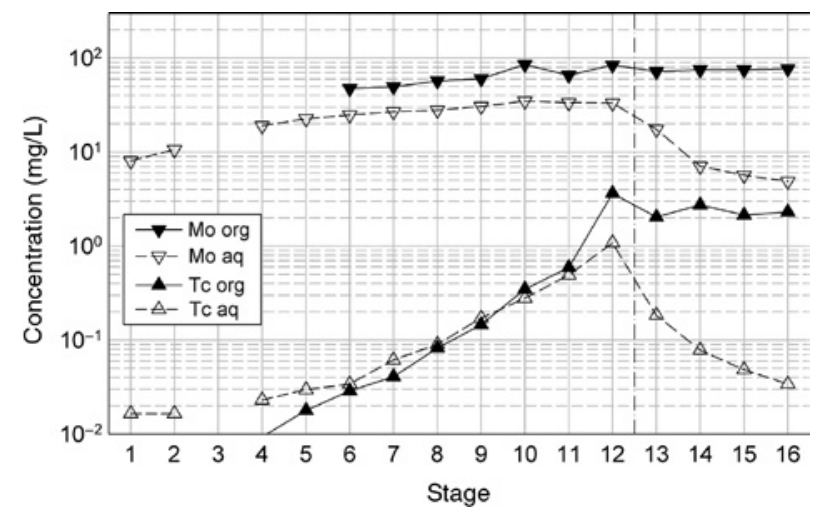

Figure 11: EURO-GANEX run, part 1 (preparation of loaded solvent), extraction (stages 1-12) and scrubbing (stages 13-16): Mo and Tc concentration profiles.

[46-47] and hence is suspected in the EURO-GANEX solvent system.

Mo and Tc concentration profiles are shown in Figure 11. Tc is most likely extracted as anionic pertechnetate and is thereby affected by nitrate competition (i.e. being less well extracted at higher nitric acid concentration). The profile indicates that Tc was well extracted in the extraction section and remained well extracted across the lower acidity scrub section. Molybdenum was also extracted in the extraction section and remained in the organic phase across the scrubbing section. Again, this behaviour is consistent with previously reported distribution ratios [22].

\subsubsection{Part 2, TRU back extraction}

The flow-sheet for the second day run is shown in Figure 12. TRU were stripped from the loaded solvent by contacting with a solution of $\mathrm{SO}_{3}$ - $\mathrm{Ph}$-BTP and AHA in $0.5 \mathrm{~mol} / \mathrm{L} \mathrm{HNO}_{3}$. Co-stripped Ln were re-extracted into fresh solvent. The solvent exiting the TRU stripping section, containing the $\mathrm{Ln}$, was finally stripped by contacting with $0.01 \mathrm{~mol} / \mathrm{L}$ $\mathrm{HNO}_{3}$. The test was run for $6 \mathrm{~h}$ to attain steady state.

$\mathrm{Np}, \mathrm{Pu}$ (Figure 13) and Am (Figure 14) were well stripped from the loaded organic phase in the TRU stripping section (stages 7-12). Apparently, Pu was not further stripped in stages 10-12. This may be an effect of some background contamination. In any case, this represented only a very small part of initial organic Pu concentration. TRU concentration profiles in the Ln re-extraction section (stages 1-6) were flat, showing that they were not re-extracted and remained in aqueous phase as intended.

The total Ln concentration profile (Figure 14) shows that Ln were efficiently separated from TRU. The fraction 


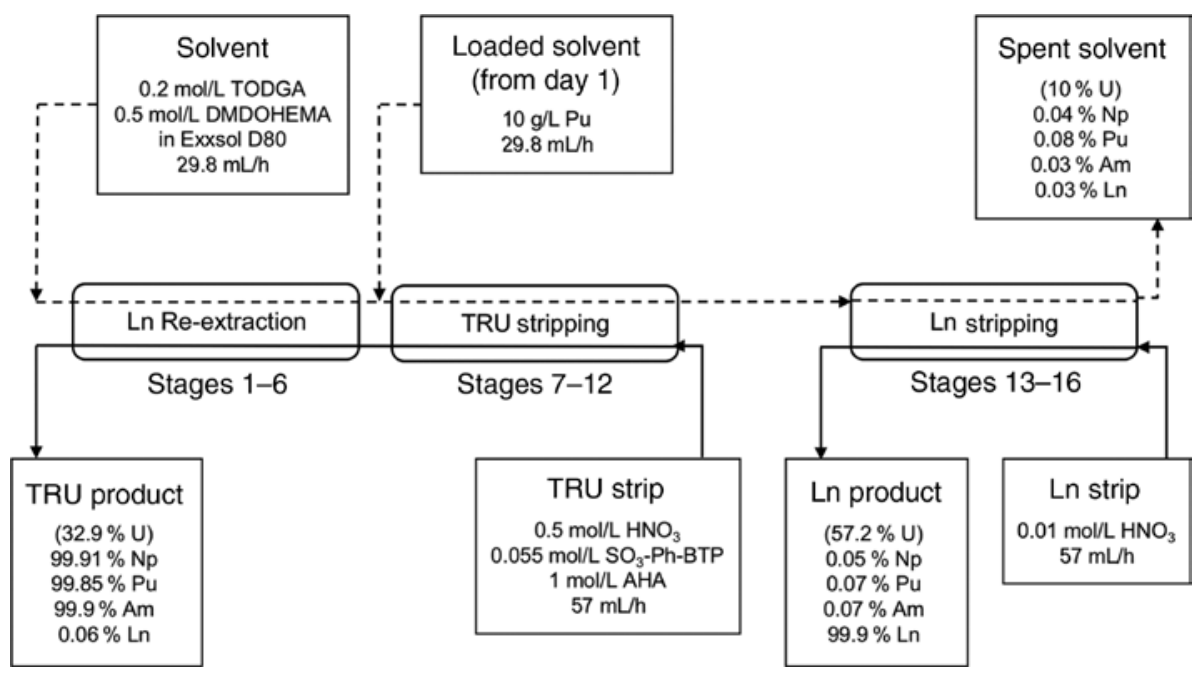

Figure 12: EURO-GANEX run part 2, TRU back extraction: flow-sheet with measured flow rates and recoveries (relative to concentrations in loaded solvent).

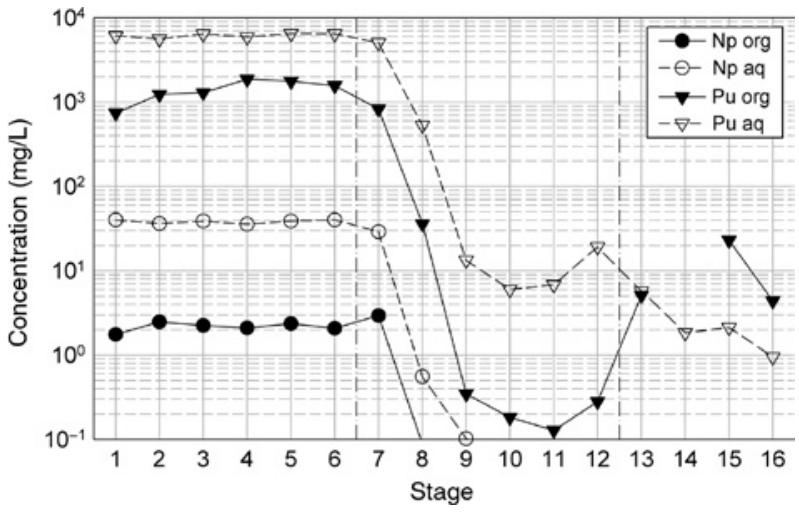

Figure 13: EURO-GANEX run, part 2 (stages 1-6, Ln re-extraction; stages 7-12, TRU stripping; stages 13-16, Ln stripping): Np and Pu concentration profiles.

of Ln stripped from the organic phase together with the TRU in the TRU stripping section (stages 7-12) was reextracted into fresh solvent in the Ln re-extraction section (stages 1-6). Thus, the losses of Ln to the TRU product solution were below $0.1 \%$. Finally, Ln ions were efficiently stripped into $0.01 \mathrm{~mol} / \mathrm{L} \mathrm{HNO}_{3}$ in the Ln stripping section (stages 13-16).

Further to $\mathrm{Np}, \mathrm{Pu}, \mathrm{Am}$ and $\mathrm{Cm}$, the TRU product solution contained $\approx 15 \mathrm{mg} / \mathrm{L} \mathrm{U}, \approx 10 \mathrm{mg} / \mathrm{L} \mathrm{Zr}, \approx 30 \mathrm{mg} / \mathrm{L}$ Mo and $\approx 0.1 \mathrm{mg} / \mathrm{L}$ lanthanides. Analyses for other fission products were either below detection limit or inconsistent, which is understandable considering their rather low concentrations in the organic feed (see Table 2, column "loaded solvent"). The lanthanides product solution (which in an industrial situation would be vitrified together with the raffinate from the EURO-GANEX run part 1) contained

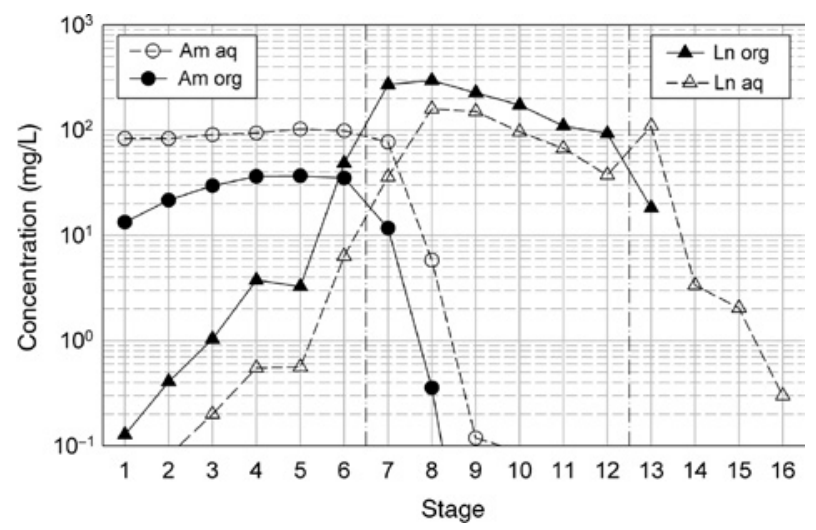

Figure 14: EURO-GANEX run, part 2 (stages 1-6, Ln re-extraction; stages 7-12, TRU stripping; stages 13-16, Ln stripping): Am and total $\operatorname{Ln}(=\mathrm{La}-\mathrm{Dy})$ concentration profiles.

$26 \mathrm{mg} / \mathrm{L} \mathrm{U}, \approx 4 \mathrm{mg} / \mathrm{L} \mathrm{Pu}$ and $\approx 0.05 \mathrm{mg} / \mathrm{L}$ Am. Finally, the spent solvent (which in an industrial situation would be recycled to the extraction section) contained $\approx 4 \mathrm{mg} / \mathrm{L} \mathrm{U}$, $\approx 0.02 \mathrm{mg} / \mathrm{L} \mathrm{Np}, \approx 4 \mathrm{mg} / \mathrm{L} \mathrm{Pu}, \approx 0.02 \mathrm{mg} / \mathrm{L} \mathrm{Am},<0.1 \mathrm{mg} / \mathrm{L} \mathrm{Ln}$, $\approx 5 \mathrm{mg} / \mathrm{L} \mathrm{Mo},<1 \mathrm{mg} / \mathrm{L} \mathrm{Ru}$.

\subsubsection{EURO-GANEX (GANEX second cycle) summary}

A hot EURO-GANEX process has successfully been demonstrated. The solvent efficiently co-extracted $10 \mathrm{~g} / \mathrm{L} \mathrm{Pu}$, together with $\mathrm{Np}, \mathrm{Am}$ and lanthanides from the GANEX first cycle raffinate. Zr and Mo co-extraction was observed. Other fission products were well rejected. Using a solution containing $\mathrm{SO}_{3}-\mathrm{Ph}$-BTP and AHA, all TRU elements were efficiently stripped while lanthanides were retained in the 
solvent. Co-extracted $\mathrm{Zr}$ and Mo were also stripped. Thus, in order to reduce $\mathrm{Zr}$ and Mo losses to the TRU product solution, their extraction must be suppressed or ways of scrubbing them from the loaded solvent must be devised.

\section{Conclusions}

A new separation process suitable for homogenous reprocessing of major $(\mathrm{U}, \mathrm{Pu})$ and minor $(\mathrm{Np}, \mathrm{Am}, \mathrm{Cm})$ actinides in future closed fuel cycles has successfully been demonstrated with irradiated fast reactor fuel. This process involves two solvent extraction cycles, a first one to recover uranium and a second one to recover the TRU.

As expected from experience with an earlier test [17], $\mathrm{U}$ removal in the first cycle process proved to be highly efficient with less than $0.1 \% \mathrm{U}$ routed to the aqueous raffinate containing the TRU actinide fraction. This was in good agreement with predictions from initial flow-sheet calculations. $\mathrm{Pu}, \mathrm{MA}$ and $\mathrm{Ln}$ were not extracted and routed together with $97 \%$ of the Np to the raffinate. Tc extraction was less well predicted. Compared to the earlier test, this hot test has extended experience with the GANEX first cycle by reprocessing fast reactor fuel with a much higher plutonium concentration and by running the test in short residence time centrifugal contactors.

TRU were recovered in the second cycle process with high efficiency (99.9\%), together with only $0.06 \%$ of the lanthanides inventory and the major fraction of $\mathrm{Zr}$ and Mo.

The sum of the TRU fractions lost to the first cycle solvent, the second cycle raffinate, second cycle lanthanide product and second cycle solvent are $3.3 \%$ (Np), $0.26 \%(\mathrm{Pu})$ and $0.11 \%(\mathrm{Am})$, i. e. overall decontamination factors of $D F_{\mathrm{Np}}=30, D F_{\mathrm{Pu}}=380$ and $D F_{\mathrm{Am}}=910$. The TRU product decontamination factors for $\mathrm{U}$ and lanthanides are $D F_{\mathrm{U}}=3300$ and $D F_{\mathrm{Ln}}=1700$, respectively.

The EURO-GANEX process has thus been successfully demonstrated with high plutonium content irradiated fast reactor fuel $(10 \mathrm{~g} / \mathrm{L} \mathrm{Pu}$ in the HA feed) and in centrifugal contactors for the first time. Improved results using a simplified flowsheet were obtained compared to the previously reported test using a surrogate feed [31].

\section{Outlook}

Despite the successful hot demonstration of the EUROGANEX process, ongoing investigations aim at process optimisation. One direction of research is simplifying the solvent formulation. While DMDOHEMA is required to ensure a sufficient plutonium loading capacity, its presence gives rise to the co-extraction of molybdenum. An improved solvent has been developed, comprising $0.5 \mathrm{~mol} / \mathrm{L} N, N, N^{\prime}, N^{\prime}$-tetra-n-decyl-2,4dimethyl-3-oxapentane diamide in $n$-dodecane [48]. This solvent has sufficient plutonium loading capacity $(>30$ $\mathrm{g} / \mathrm{L}$ at $5 \mathrm{~mol} / \mathrm{L} \mathrm{HNO}_{3}$ ) and significantly lower distribution ratios for some fission products and has the potential to replace the current EURO-GANEX solvent. Further investigations address the replacement of the sulfur containing stripping agent, $\mathrm{SO}_{3}$ - $\mathrm{Ph}$-BTP, with a $\mathrm{CHON}$ [49] compound such as a hydrophilic 2,6-bis-triazolyl-pyridine [50-51].

\section{Annex - Experimental}

\subsection{Chemicals}

DEHiBA and DMDOHEMA were synthesised by Pharmasynthèse (France), TODGA was synthesised by Technocomm (UK). Diluents used were TPH (Novasep, France) and Exxsol D80 (ExxonMobil). $\mathrm{SO}_{3}$-Ph-BTP was synthesised as described in references [29, 52]. All other chemicals used were from Merck (Germany) or Sigma-Aldrich (Germany).

\subsection{Centrifugal contactor setup}

The centrifugal contactor setup was installed in a hot cell. It consisted of 16 BXP 012 contactors $(12 \mathrm{~mm}$ diameter) from Rousselet-Robatel (France). Piston pumps were used for feeding solutions. For further details see Ref. [53].

\subsection{Analytics}

At the end of a test, the system, i. e. pumps and centrifugal contactors, were simultaneously shut down. The liquids inside the contactor wells were emptied and centrifuged before the organic and the aqueous phases were separately collected and sampled. Organic samples were initially backextracted using $0.1 \mathrm{~mol} / \mathrm{L} \mathrm{HNO}_{3}$ with an organic to aqueous ratio of 100 , i.e. $0.1 \mathrm{~mL}$ sample in $10 \mathrm{~mL}$ dilute $\mathrm{HNO}_{3}$, yielding a dilution factor of 100. Further dilutions were done in $1 \mathrm{~mol} / \mathrm{L} \mathrm{HNO}_{3}$. All aqueous samples were directly diluted into $1 \mathrm{~mol} / \mathrm{L} \mathrm{HNO}_{3}$. The metal ion concentrations were determined by ICP-MS analysis (Thermo Fisher ELEMENT 2). Each sample was analysed with three dilution factors, i. e. $10^{3}, 10^{4}$ and $10^{6}$. The limit of detection is in the range of $0.001 \mathrm{mg} / \mathrm{L}$. 
Acknowledgement: Financial support for this research was provided by the European Commission via the following projects: ACSEPT (contract № FP7-CP-2007-211267), SACSESS (contract № FP7-Fission-2012-323282) and GENIORS (Horizon 2020 grant agreement № 755171).

\section{References}

1. The Nuclear Fuel Report. World Nuclear Association (2017).

2. Poinssot, C., Bourg, S., Ouvrier, N., Combernoux, N., Rostaing, C., Vargas-Gonzalez, M., Bruno, J.: Assessment of the environmental footprint of nuclear energy systems. Comparison between closed and open fuel cycles. Energy 69, 199 (2014).

3. Poinssot, C., Bourg, S., Boullis, B.: Improving the nuclear energy sustainability by decreasing its environmental footprint. Guidelines from life cycle assessment simulations. Progr. Nucl. Energy 92, 234 (2016).

4. Modolo, G., Geist, A., Miguirditchian, M.: Minor actinide separations in the reprocessing of spent nuclear fuels: recent advances in Europe. In: R. Taylor (Ed.), Reprocessing and Recycling of Spent Nuclear Fuel (2015), Woodhead Publishing, Cambridge, UK.

5. Homogeneous versus heterogeneous recycling of transuranics in fast nuclear reactors. NEA No. 7077, OECD, Nuclear Energy Agency (NEA), Paris (2012).

6. State-of-the-art report on the progress of nuclear fuel cycle chemistry. NEA No. 7267, OECD, Nuclear Energy Agency (NEA), Paris (2018).

7. Aneheim, E., Ekberg, C., Fermvik, A., Foreman, M. R. S., Retegan, T., Skarnemark, G.: A TBP/BTBP-based GANEX separation process. Part 1: feasibility. Solvent Extr. Ion Exc. 28, 437 (2010).

8. Aneheim, E., Ekberg, C., Foreman, M. R. S.: A TBP/BTBP-based GANEX separation process - part 3: fission product handling. Solvent Extr. Ion Exc. 31, 237 (2013).

9. Halleröd, J., Ekberg, C., Löfström-Engdahl, E., Aneheim, E.: Development of the Chalmers grouped actinide extraction process. Nukleonika 60, 829 (2015).

10. Foreman, M. R. S., Hudson, M. J., Drew, M. G. B., Hill, C., Madic, C.: Complexes formed between the quadridentate, heterocyclic molecules 6,6'-bis-(5,6-dialkyl-1,2,4-triazin-3-yl)2,2'-bipyridine (BTBP) and lanthanides(III): implications for the partitioning of actinides(III) and lanthanides(III). Dalton Trans. 1645 (2006).

11. Geist, A., Hill, C., Modolo, G., Foreman, M. R. S. J., Weigl, M., Gompper, K., Hudson, M. J., Madic, C.: 6,6'-bis (5,5,8,8-tetramethyl-5,6,7,8-tetrahydro-benzo[1,2,4]triazin-3-yl)[2,2']bipyridine, an effective extracting agent for the separation of americium(III) and curium(III) from the lanthanides. Solvent Extr. Ion Exc. 24, 463 (2006).

12. Todd, T. A., Vienna, J. D., Bresee, J. C., Gray, K., Kung, S., Paviet, P.: The United States material recovery and waste form development program. In Proc. Internat. Conf. GLOBAL 2015 (Nuclear Fuel Cycle for a Low-carbon Future), Paris, France, 20-24 September 2015; pp 1664-1669.

13. Runde, W. H., Mincher, B. J.: Higher oxidation states of americium: preparation, characterization and use for separations. Chem. Rev. 111, 5723 (2011).
14. Mincher, B. J., Martin, L. R., Schmitt, N. C.: Diamylamylphosphonate solvent extraction of $\mathrm{Am}(\mathrm{VI})$ from nuclear fuel raffinate simulant solution. Solvent Extr. Ion Exc. 30, 445 (2012).

15. Adnet, J.-M., Miguirditchian, M., Hill, C., Hérès, X., Lecomte, M., Masson, M., Brossard, P., Baron, P.: Development of new hydrometallurgical processes for actinide recovery: GANEX concept. In Proc. Internat. Conf. GLOBAL 2005 (Nuclear Energy Systems for Future Generation and Global Sustainability), Tsukuba, Japan, 9-13 October 2005.

16. Miguirditchian, M., Chareyre, L., Hérès, X., Hill, C., Baron, P., Masson, M.: GANEX: adaptation of the DIAMEX-SANEX process for the group actinide separation. In Proc. Internat. Conf. GLOBAL 2007 (Advanced Nuclear Fuel Cycles and Systems), Boise, Idaho, USA, 9-13 September 2007.

17. Miguirditchian, M., Sorel, C., Camès, B., Bisel, I., Baron, P., Espinoux, D., Calor, J.-N., Viallesoubranne, C., Lorrain, B., Masson, M.: HA demonstration in the Atalante facility of the GANEX $1^{\text {st }}$ cycle for the selective extraction of uranium from HLW. In Proc. Internat. Conf. GLOBAL 2009 (The Nuclear Fuel Cycle: Sustainable Options \& Industrial Perspectives), Paris, France, 6-11 September 2009.

18. Berthon, L., Morel, J. M., Zorz, N., Nicol, C., Virelizier, H., Madic, C.: DIAMEX process for minor actinide partitioning: hydrolytic and radiolytic degradations of malonamide extractants. Sep. Sci. Technol. 36, 709 (2001).

19. Miguirditchian, M., Roussel, H., Chareyre, L., Baron, P., Espinoux, D., Calor, J.-N., Viallesoubranne, C., Lorrain, B., Masson, M.: HA demonstration in the Atalante facility of the GANEX $2^{\text {nd }}$ cycle for the grouped TRU extraction. In Proc. Internat. Conf. GLOBAL 2009 (The Nuclear Fuel Cycle: Sustainable Options \& Industrial Perspectives), Paris, France, 6-11 September 2009.

20. Bourg, S., Hill, C., Caravaca, C., Rhodes, C., Ekberg, C., Taylor, R., Geist, A., Modolo, G., Cassayre, L., Malmbeck, R., Harrison, M., de Angelis, G., Espartero, A., Bouvet, S., Ouvrier, N.: ACSEPT - partitioning technologies and actinide science: towards pilot facilities in Europe. Nucl. Eng. Des. 241, 3427 (2011).

21. Sasaki, Y., Sugo, Y., Suzuki, S., Tachimori, S.: The novel extractants, diglycolamides, for the extraction of lanthanides and actinides in $\mathrm{HNO}_{3} / \mathrm{n}$-dodecane system. Solvent Extr. Ion Exc. 19, 91 (2001).

22. Carrott, M., Geist, A., Hérès, X., Lange, S., Malmbeck, R., Miguirditchian, M., Modolo, G., Wilden, A., Taylor, R.: Distribution of plutonium, americium and interfering fission products between nitric acid and a mixed organic phase of TODGA and DMDOHEMA in kerosene, and implications for the design of the "EUROGANEX” process. Hydrometallurgy 152, 139 (2015).

23. Carrott, M. J., Gregson, C. R., Taylor, R. J.: Neptunium extraction and stability in the GANEX solvent: 0.2 M TODGA/0.5 M DMDOHEMA/kerosene. Solvent Extr. Ion Exc. 31, 463 (2013).

24. Bell, K., Geist, A., McLachlan, F., Modolo, G., Taylor, R., Wilden, A.: Nitric acid extraction into TODGA. Proc. Chem. 7, 152 (2012).

25. Bell, K., Carpentier, C., Carrott, M., Geist, A., Gregson, C., Hérès, X., Magnusson, D., Malmbeck, R., McLachlan, F., Modolo, G., Müllich, U., Sypula, M., Taylor, R., Wilden, A.: Progress towards the development of a new GANEX process. Proc. Chem. 7, 392 (2012).

26. Brown, J., McLachlan, F., Sarsfield, M., Taylor, R., Modolo, G., Wilden, A.: Plutonium loading of prospective grouped actinide extraction (GANEX) solvent systems based on diglycolamide extractants. Solvent Extr. Ion Exc. 30, 127 (2012). 
27. Cuillerdier, C., Musikas, C., Hoel, P., Nigond, L., Vitart, X.: Malonamides as new extractants for nuclear waste solutions. Sep. Sci. Technol. 26, 1229 (1991).

28. Sypula, M., Wilden, A., Schreinemachers, C., Malmbeck, R., Geist, A., Taylor, R., Modolo, G.: Use of polyaminocarboxylic acids as hydrophilic masking agents for fission products in actinide partitioning processes. Solvent Extr. Ion Exc. 30, 748 (2012).

29. Geist, A., Müllich, U., Magnusson, D., Kaden, P., Modolo, G., Wilden, A., Zevaco, T.: Actinide(III)/lanthanide(III) separation via selective aqueous complexation of actinides(III) using a hydrophilic 2,6-bis(1,2,4-triazin-3-yl)-pyridine in nitric acid. Solvent Extr. Ion Exc. 30, 433 (2012).

30. Carrott, M. J., Fox, O. D., Maher, C. J., Mason, C., Taylor, R. J., Sinkov, S. I., Choppin, G. R.: Solvent extraction behavior of plutonium (IV) ions in the presence of simple hydroxamic acids. Solvent Extr. Ion Exc. 25, 723 (2007).

31. Carrott, M., Bell, K., Brown, J., Geist, A., Gregson, C., Hérès, X., Maher, C., Malmbeck, R., Mason, C., Modolo, G., Müllich, U., Sarsfield, M., Wilden, A., Taylor, R.: Development of a new flowsheet for co-separating the transuranic actinides: the “EURO-GANEX” process. Solvent Extr. Ion Exc. 32, 447 (2014).

32. Carrott, M., Maher, C., Mason, C., Sarsfield, M., Taylor, R.: “TRUSANEX": a variation on the EURO-GANEX and i-SANEX processes for heterogeneous recycling of actinides $\mathrm{Np}-\mathrm{Cm}$. Sep. Sci. Technol. 51, 2198 (2016).

33. Peakall, K. A., Antill, J. E.: Oxidation of uranium dioxide in air at 350-1000 ${ }^{\circ}$ C. J. Nucl. Mater. 2, 194 (1960).

34. Bisson, J., Dinh, B., Huron, P., Huel, C.: PAREX, a numerical code in the service of La Hague plant operations. Proc. Chem. 21, 117 (2016).

35. Miguirditchian, M., Sorel, C., Camès, B., Bisel, I., Baron, P.: Extraction of uranium $(\mathrm{VI})$ by $\mathrm{N}, \mathrm{N}$ '-di-(2-ethylhexyl)isobutyramide (DEHIBA): from the batch experimental data to the countercurrent process. Proc. Internat. Solvent Extr. Conf. (ISEC 2008), Moyer, B. A., Ed. Tucson, Arizona, USA, 15-19 September 2008.

36. Sorel, C., Montuir, M., Balaguer, C., Baron, P., Dinh, B., Hérès, X., Pacary, V., Roussel, H.: A powerful tool to model and simulate solvent extraction operations. Proc. Internat. Solvent Extr. Conf. (ISEC 2011), Santiago, Chile, 3-7 October 2011.

37. Moeyaert, P., Abiad, L., Sorel, C., Dufrêche, J. F., Ruas, A., Moisy, P., Miguirditchian, M.: Density and activity of pertechnetic acid aqueous solutions at $T=298.15 \mathrm{~K}$. J. Chem. Thermodyn. 91, 94 (2015).

38. Moeyaert, P., Dumas, T., Guillaumont, D., Kvashnina, K., Sorel, C., Miguirditchian, M., Moisy, P., Dufrêche, J.-F.: Modeling and speciation study of uranium(VI) and technetium(VII) coextraction with DEHiBA. Inorg. Chem. 55, 6511 (2016).

39. Drake, V. A.: Extraction chemistry of neptunium. In: W. W. Schulz, L. L. Burger, J. D. Navratil, K. P. Bender (Eds.), Science and Technology of Tributyl Phosphate (1990), CRC Press, Boca Raton, Florida.

40. Moulin, J. P.: On the kinetics of redox reaction of neptunium in nitric acid - oxidation of neptunium(IV) to neptunium(V) - oxidation of neptunium(V) to neptunium(VI) by nitric acid, catalyzed by nitrous acid. CEA-R-4912, Commissariat à l'Énergie Atomique, France (1978).
41. Chen, H., Taylor, R., Jobson, M., Woodhead, D., Masters, A.: Development and validation of a flowsheet simulation model for neptunium extraction in an advanced PUREX process. Solvent Extr. Ion Exc. 34, 297 (2016).

42. Chen, H., Taylor, R. J., Jobson, M., Woodhead, D. A., Boxall, C., Masters, A. J., Edwards, S.: Simulation of neptunium extraction in an advanced PUREX process - model improvement. Solvent Extr. Ion Exc. 35, 1 (2017).

43. Moeyaert, P., Miguirditchian, M., Masson, M., Dinh, B., Hérès, X., De Sio, S., Sorel, C.: Experimental and modelling study of ruthenium extraction with tri- $n$-butylphosphate in the PUREX process. Chem. Eng. Sci. 158, 580 (2017).

44. Modolo, G., Asp, H., Vijgen, H., Malmbeck, R., Magnusson, D., Sorel, C.: Demonstration of a TODGA-based continuous countercurrent extraction process for the partitioning of actinides from a simulated PUREX raffinate, part II: centrifugal contactor runs. Solvent Extr. Ion Exc. 26, 62 (2008).

45. Magnusson, D., Christiansen, B., Glatz, J. P., Malmbeck, R., Modolo, G., Serrano-Purroy, D., Sorel, C.: Demonstration of a TODGA based extraction process for the partitioning of minor actinides from a PUREX raffinate. Part III: centrifugal contactor run using genuine fuel solution. Solvent Extr. Ion Exc. 27, 26 (2009).

46. Serrano-Purroy, D., Baron, P., Christiansen, B., Malmbeck, R., Sorel, C., Glatz, J. P.: Recovery of minor actinides from HLLW using the DIAMEX process. Radiochim. Acta 93, 351 (2005).

47. Geist, A., Gompper, K.: Miniature DIAMEX processes in a hollow fibre module micro-plant: process development and optimisation. Radiochim. Acta 96, 211 (2008).

48. Malmbeck, R., Magnusson, D., Geist, A.: Modified diglycolamides for grouped actinide separation. J. Radioanal. Nucl. Chem. 314, 2531 (2017).

49. Madic, C., Hudson, M. J.: High-level liquid waste partitioning by means of completely incinerable extractants. EUR 18038 , European Commission, Luxembourg (1998).

50. Macerata, E., Mossini, E., Scaravaggi, S., Mariani, M., Mele, A., Panzeri, W., Boubals, N., Berthon, L., Charbonnel, M.-C., Sansone, F., Arduini, A., Casnati, A.: Hydrophilic clicked 2,6-bistriazolyl-pyridines endowed with high actinide selectivity and radiochemical stability: toward a closed nuclear fuel cycle. J. Amer. Chem. Soc. 138, 7232 (2016).

51. Wagner, C., Mossini, E., Macerata, E., Mariani, M., Arduini, A., Casnati, A., Geist, A., Panak, P. J.: Time-resolved laser fluorescence spectroscopy study of the coordination chemistry of a hydrophilic CHON [1,2,3-triazol-4-yl]pyridine ligand with Cm(III) and Eu(III). Inorg. Chem. 56, 2135 (2017).

52. Traister, G. L., Schilt, A. A.: Water-soluble sulfonated chromogenic reagents of the ferroin type and determination of iron and copper in water, blood serum, and beer with the tetraammonium salt of 2,4-bis(5,6-diphenyl-1,2,4-triazin-3-yl)pyridinetetrasulfonic acid. Anal. Chem. 48, 1216 (1976).

53. Magnusson, D., Christiansen, B., Foreman, M. R. S., Geist, A., Glatz, J. P., Malmbeck, R., Modolo, G., Serrano-Purroy, D., Sorel, C.: Demonstration of a SANEX process in centrifugal contactors using the $\mathrm{CyMe}_{4}$-BTBP molecule on a genuine fuel solution. Solvent Extr. Ion Exc. 27, 97 (2009). 